\title{
INFORMALLY RAW MILK AND KAREISH CHEESE INVESTIGATION ON THE OCCURRENCE OF TOXIGENIC ESCHERICHIA COLIIN QENA CITY, EGYPT WITH EMPHASIS ON MOLECULAR CHARACTERIZATION
}

\author{
Sabry A. Hassan ${ }^{*}$ and Laila M. Elmalt ${ }^{* *}$ \\ *Department of Microbiology and **Department of Food Hygiene \\ Faculty of Veterinary Medicine, South Valley University, Qena, Egypt
}

\begin{abstract}
:
The informally raw milk and Kareish cheese sold in Qena city (Upper Egypt) were analyzed to determine the presence of toxigenic E.coli. The isolates were screened for the presence of verotoxigenic E.coli (VTEC) and enterotoxigenic E.coli (ETEC) by Polymerase Chain Reaction (PCR). Bio-resistance to antimicrobial agents was evaluated by the disk diffusion method. $E$ coli were recovered from $38(76 \%)$ of raw milk and $11(47.8 \%)$ of Kareish cheese samples. Three (6.1\%) of the E.coli isolates were VTEC and none of them hat eaeA gene encoded a pathogenicity island typical of E.coli 0157:H7 (EHEC). PCR of enterotoxins showed that only one isolate carried LT enterotoxins of ETEC. Bio-resistance was frequently observed to nalidixic acid (42.9\%), ampicillin (32.7\%), tetracycline (22.4\%), trimethoprim-sulfamethoxazol (14.3\%), ciprofloxacin (4.1\%) and cefoxtin (2.0\%). Results suggested a possibility of potential public health threat of E.coli originating from raw milk sources.
\end{abstract}

\section{INTRODUCTION:}

Markets and consumers for raw milk and their products have existed in many parts of the world. Being a highly nutritious medium, therefore many bacteria including spoilage and pathogenic bacteria can grow and propagate in it. Generally, bacteria in the milk can occur through colonization of the teat canal or an infected udder (clinical and subclinical mastitis) or gets contaminated at various stages be it from the animal, milker (manual as well as automated), extraneous dirt or unclean process water (Gruetzmacher and Bradley, 1999; Hayes et al., 2001).
Several studies have identified milkborne pathogens including Shiga-toxin producing Escherichia coli (STEC) in farm bulk tank milk (BTM) (Moustafa et al., 1983; Lovett et al., 1987; McManus and Lanier, 1987; Rohrbach et al., 1992; O'Donnell, 1995; Rahn et al., 1997; Steele et al., 1997).

Many microorganisms can get access to milk and its products, among these is E.coli. which is often used as a marker organisms. Recovery and counting of Escherichia coli is used as reliable indicator of fecal contamination and indicate a possible presence of enteropathogenic and/or toxigenic microorganisms which 
constitute a public health hazard. Escherichia coli is one of the main inhabitants of the intestinal tract of most mammalian species, including humans and birds. Most E.coli are harmless, but some known as pathogenic bacteria causing severe intestinal and extraintestinal diseases in man (Kaper et al., 2004). These potentially harmful E.coli are classified into categories based on the production of virulence factors and on the clinical manifestations that they cause. In addition to the presence of E.coli denoting fecal pollution, the presence of virulence- related genes in E.coli strains refer to the pathogenicity of the isolates. Previous studies documented the equation of some E.coli isolates from raw milk and its products for virulence markers (Klie et al., 1997; Jajarao and Henning, 2001; Holko et al., 2006; Paneto et al., 2007).

The present study aimed to investigate the occurrence of toxigenic E.coli isolates in raw milk and Kareish cheese using PCR assay and monitor the isolates to bio-resistance to different antimicrobial agents.

\section{MATERIALS AND METHODS:}

\section{Sample collection:}

A total of fifty raw milk and twenty-three Kareish cheese samples were randomly collected from different shops and distributors in Qena city. Samples were delivered to the laboratory in a cool box and tested within $24 \mathrm{hr}$.

\section{Isolation and identification of E.coli:}

Raw milk and Kareish cheese samples were taken for bacteriological analyses to detect the presence of E.coli. Concerning cheese samples, $25 \mathrm{~g}$ were dispensed into a sterile flask containing $225 \mathrm{ml}$ of buffered peptone water and homogenized with lab stomacher. E.coli confirmation was achieved by colony morph- ology on eosin methelene blue agar (EMBScharlau, Spain, EU) and performing API 20E (bioMérieux-France). Ninety-four E.coli stains were recovered from 50 raw milk and 23 cheese samples, and one isolates from each samples was used for further studies.

\section{Bio-resistance of the isolated E.coli to some antimicrobial agents:}

The susceptibility of isolates to different antimicrobial agents was done by disk diffusion method using commercial disks (Bauer et al., 1966). The antimicrobial agents tested were the following: nalidixic acid (30 $\mu \mathrm{g})$, ampicillin (10U), tetracycline $(30 \mu \mathrm{g})$, trimethoprimsulphamethoxazol ( $25 \mu \mathrm{g})$, ciprofloxacin $(5 \mu \mathrm{g})$, cefoxtin $(30 \mu \mathrm{g})$, amikacin $(30 \mu \mathrm{g})$, imipenem (10 $\mu \mathrm{g})$ and netilmicin $(30 \mu \mathrm{g})$.

\section{Polymerase chain reaction (PCR):}

Bacterial strains were overnight grown in trypticase soy agar (TSA-Scharlau, Spain, EU) at $37^{\circ} \mathrm{C}$. One colony was suspended in $100 \mu \mathrm{l}$ of sterile distilled water. After boiling the suspension for $10 \mathrm{~min}$, the supernatant was used as a template for PCR. Gene regions coding for the following pathogenic properties were amplified for each bacterial isolate: heat-labile toxin (LT), heat-stable toxin (ST), Shiga-like Toxin 1 and 2 (stx1, stx2), and enteropathogenic attachment and effacement (eaeA) using specific primers. Specific primers and amplification conditions for the different pathogenic gene coding regions were employed as previously described (Brian et al., 1992; China et al., 1996 and Matar et al., 2002). Details are shown in Table (1). For cycling, a PXE-0.5 thermal cycler (THERMO, Electron Corporation, Milford, MA, USA) was used. Amplified gene products were verified by gel electrophoresis $(2 \%$ agarose) at $120 \mathrm{~V}$ for $40 \mathrm{~min}$ and visualised under ultraviolet light. 
Table (1): Sequences and predicted size of PCR amplification products of the oligonuleotide primers used

\begin{tabular}{||l|c|c|c||}
\hline \multicolumn{1}{|c|}{ Pathogenic factor } & Primer Sequences & $\begin{array}{c}\text { Predicted Size } \\
\text { (bp) }\end{array}$ & Reference \\
\hline Shiga like toxin 1 (stx1) & $\begin{array}{c}\text { aaatcgccattcgttgactacttct } \\
\text { tgccattctggcaactcgcgatgca }\end{array}$ & 366 & Brian et al., 1992 \\
\hline Shiga like toxin 2 (stx2) & $\begin{array}{c}\text { cgatcgtcactcactggttcatca } \\
\text { ggatattctcccactctgacacc }\end{array}$ & 282 & Brian et al., 1992 \\
\hline $\begin{array}{l}\text { Enteropathogenic attachment and } \\
\text { effacement (eaeA) }\end{array}$ & $\begin{array}{c}\text { aggettcgtcacatgtg } \\
\text { ccatcgtcaccagagga }\end{array}$ & 579 & China et al., 1996 \\
\hline Heat labile toxin (LT) & $\begin{array}{c}\text { tctcattgtgcatacggagc } \\
\text { Ccatactgattgcegcaat }\end{array}$ & 320 & Matar et al., 2002 \\
\hline
\end{tabular}

\section{RESULTS AND DISCUSSION:}

E.coli is not only regarded as an indicator of faecal contamination but more likely as an indicator of poor hygiene and sanitary practices during milking and further handling. E.coli was isolated in $38(76.0 \%)$ out of the 50 tested raw milk samples and $11(47.8 \%)$ out of 23 Kareish cheese samples (Table2). Milk can be easily contaminated by infected food handlers who practice poor personal hygiene or by water containing human discharges. Higher prevalence of E.coli was reported by many authors. In Egypt, Aly and Galal, (2002) showed the presence of E.coli in raw milk and the number reduced in the heat treated one. In India, the raw milk and products were heavily contaminated by E.coli (Soomro et al., 2002). In South Africa, Lues et al. (2003) detected a higher percentage of E.coli in raw milk. In Malaysia, Chye et al. (2004) indicated that $90 \%$ of the examined raw milk was contaminated by coliform bacteria and $65 \%$ were E.coli positive.

PCR showed that three isolates $(6.1 \%)$ carried stx2 gene, and one isolate (2.0\%) of stx1 gene (Table2), a value much higher than registered in Spain $(0.4 \%)$ by Quinto and Cepeda, (1997), in Ontario $(0.87 \%)$ by Steel et al. (1997), and in Germany (3.9\%) by Klie et al. (1997). Meanwhile, was similar Paneto et al., (2007) who reported $6 \%$ in raw milk cheese in Brazil. In the other hand, less than $13 \%$ reported by Vernozy-Rozand et al. (2005) in French cheese. The results showed that, three of the four isolates of E.coli encoded for ShigaToxin 2 gene, while one strain encoded for Shiga-Toxin 1 gene and none of Shiga-Toxin carried strains hat eaeA gene encoded a pathogenicity island typical of E.coli $0157: \mathrm{H} 7$ (EHEC). On the contrary, Montenegro et al. (1990) reported that most of the STEC isolates of bovine origin encoded for Shiga-Toxin 1 gene. STEC have been associated with human disease. Foods of animal origin including raw milk have been implicated as important vehicles for STEC infections in humans. PCR of heat labile enterotoxins encoded for ETEC showed that only one of the tested strains carried LT gene (Table 2). Frank et al. (1984) reported the presence of $3.2 \%$ of ETEC strains in milk and milk products. Paneto et al. (2007) showed that only one isolate carried the LT-II gene while the ST gene was not found. ETEC are responsible for diarrhea in children.

Most frequent resistance was observed to the following antimicrobials: nalidixic acid $(42.9 \%)$, ampicillin $(32.7 \%)$, tetracycline (22.4\%), trimethoprim-sulfamethoxazol (14.3\%), ciprofloxacin $(\mathbf{4 . 1 \% )}$ and cefoxtin $(\mathbf{2 . 0 \%})$ (Table 3). Paneto et al. (2007) examined VTEC strains from raw milk cheese, and similarly reported a high antimicrobial resistance to different antimicrobial agents and some of them were similar to those found in this study. 
Resistance to at least one or more of tested antimicrobial agents was found in $42.9 \%$ of the examined isolates. A much higher resistance was observed in $83 \%$ of $E$.coli isolated from raw milk cheese in Brazil (Paneto et al. 2007). The high level of resistance may be a consequence of the abusive uses of antimicrobials in animal therapeutics as well as in food additives used to promote animal growth.

Table (2): Frequencies of isolation of E.coli and occurrence of pathogenic coding genes of E.coli isolated from informal raw milk and Kareish cheese marketed in Qena city, Egypt

\begin{tabular}{|c|c|c|c|c|c|}
\hline \multirow{2}{*}{$\begin{array}{c}\text { Sample source } \\
(\mathrm{n}=\text { number of samples })\end{array}$} & \multirow{2}{*}{$\begin{array}{c}\text { Number of }(\%) \\
\text { E.coli isolates }\end{array}$} & \multicolumn{4}{|c|}{ Frequency of occurrence of pathogenic coding genes } \\
\hline & & stx1 & stx2 & eaeA & LT \\
\hline Raw milk $(\mathbf{n}=\mathbf{5 0})$ & $38(76.0 \%)$ & $1(2.6 \%)$ & $2(5.3 \%)$ & - & $1(2.6 \%)$ \\
\hline Kareish cheese $(n=23)$ & $11(47.8 \%)$ & - & $1(9.1 \%)$ & - & - \\
\hline Total $(n=73)$ & $49(67.1 \%)$ & $1(2.0 \%)$ & $3(6.1 \%)$ & - & $1(2.0 \%)$ \\
\hline
\end{tabular}

Table (3): Antimicrobial susceptibility testing of 49 E.coli isolates from raw milk and Kareish cheese

\begin{tabular}{||l|c|c||}
\hline \multicolumn{1}{|c|}{ Antimicrobials } & No. of resistance & \% of resistance \\
\hline Nalidixic acid (NALX) & 21 & 42.9 \\
Ampicilin (AMPC) & 16 & 32.7 \\
Tetracyclin (TET) & 11 & 22.4 \\
Trimethoprim-sulphamethoxazol (SMX/TMP) & 7 & 14.3 \\
Ciprofloxacin (CTPX) & 2 & 4.1 \\
Cefoxtin (FOX) & 1 & 2.0 \\
Amikacin (AMK) & 0 & 0 \\
Imipenem (IMIP) & 0 & 0 \\
Netilmicin (NET) & 0 & 0 \\
\hline
\end{tabular}

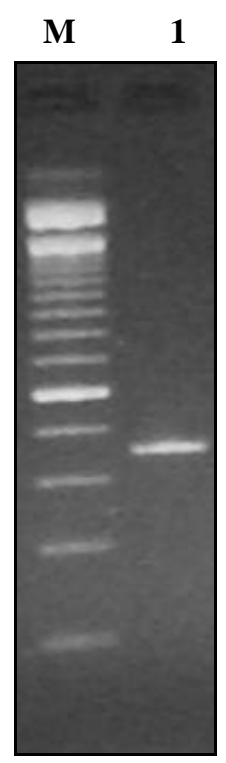

(a) stx1

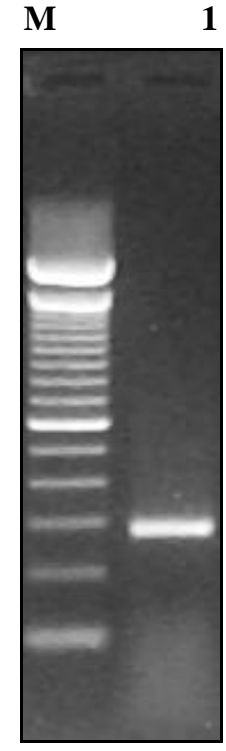

(b) stx2

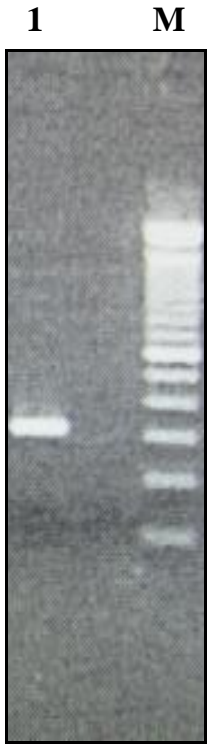

(c) LT

Figure (1): PCR amplicons of pathogenic coding genes determined in E.coli isolates from raw milk and Kareish cheese (a) stx1 366bp; (b) stx2 282bp; (c) LT 320bp. Lane M: 1Kb ladder, lane 1: test sample 


\section{CONCLUSION:}

Results clearly indicated that microbial quality and safety of raw milk and Kareish cheese produced by local farmers and distributors was unsafe. The presence of faecal indicator organism not only indicates the poor hygiene but also itself may be pathogenic. The pathogenic bacteria such as E.coli may pass to the milk; this suggests that raw milk should be considered a vehicle for the transmission of potentially pathogenic bacteria.

\section{Acknowledgments:}

Prof. Y.A. Gherbawy (molecular biology unit, Botany department, Faculty of Science, South Valley University, Qena, Egypt) for use the lab facilities and to Prof. Awad-Masalmeh (University of Veterinary Medicine, Vienna, Austria) for E.coli (VT1-VT2- eaeA) and E.coli (LT).

\section{REFERENCES:}

Aly, S. A. and Galal, E. A. (2002): Effect of milk pretreatment on the keeping quality of Domiati cheese. Pakistan Journal of Nutrition 1, 132-136.

Bauer, A. W.; Kirby, W. M. M.; Sherris, J. C. and Turck, M. (1966): Antibiotic susceptibility testing by a standardized single disk method. Amer. J. Clin. Pathol. 45, 493- 496.

Brian, M. J.; Frosolono, M.; Murray, B. E.; Miranda, A.; Lopez, E. L.; Gomez, H. F. and Cleary, T.G. (1992): Polymerase chain reaction for diagnosis of enterohemorrhagic Escherichia coli infection and hemolytic-uremic syndrome. J. Clin. Microbiol. 30, 1801-1806.

China, B.; Pirson V. and Mainil, J. (1996): Prevalence and molecular typing of attaching and effacing Escherichia coli among calf population in Belgium. J. Vet. Microbiol. 63, 256-259.

Chye, F. Y.; Abdullahb, A. and Ayobb, M. K. (2001): Bacteriological quality and safety of raw milk in Malaysia. Food Microbiology 21, 535-541.

Frank, V.; Hahn, G. and Tolle, A. (1984): Incidence and identification of enterotoxigenic Escherichia coli strains in milk and milk products. Zentral. Bakteriol Microbiol. Hyg. 257, 51-59.

Gruetzmacher, T.J. and Bradley Jr.R.L. (1999): Identification and control of processing variables that affect the quality and safety of fluid milk. J. Food Prot. 62, 625631.

Hayes, M.C.; Ralyea, R. D.; Murphy, S. C.; Carey, N. R.; Scarlett, J. M. and Boor, K. J. (2001): Identification and characterization of elevated microbial counts in bulk tank raw milk. J. Dairy Sci. 84, 292 298.

Holko, I.; Bisova, T.; Holkova, Z. and Kmet, V. (2006): Virulence markers of Escherichia coli strains isolated from traditional cheeses made from unpasteurised sheep milk in Slovakia. Food Control 17, 393396.

Jajarao, B. M. and Henning, D. R. (2001): Prevalence of foodborne pathogens in bulk tank milk. J. Dairy Sci. 84, 21572162.

Kaper, J. B.; Nataro, J. P. and Mobley, H. L. T. (2004): Pathogenic Escherichia coli. Nat. Rev. Microbiol. 2, 123-140.

Klie, H.; Timm, M.; Richter, H.; Gallien, P.; Perlberg, K. W. and Steinruck, H. (1997): Detection and occurrence of vertoxinforming and/or shigatoxin producing Escherichia coli (VTEC and/or STEC in milk): Berl. Munch. Tierarztl Wochenschr 0, 337-341. 
Lovett, J. D.; Francis, W. and Hunt, J. M. (1987): Listeria monocytogenes in raw milk: Detection, incidence, and pathogenicity. J. Food. Prot. 50, 188-192.

Lues, J. F. R.; Venter, P.; van der Westhuizen, H. (2003): Enumeration of potential microbiological hazards in milk from a marginal urban settlement in central South Africa. Food Microbiology 20, 321-326.

Matar, G. M.; Adbo, D.; Khneisser, I.; Youssef, M.; Zouheiry, H.; Adbelnour, G. and Harakeh, H. S. (2002): The multiplexPCR based detection and genotyping of diarrhoeagenic Escherichia coli diarrhoea stools. Ann. Trop. Med. Parasitol. 96, 317-324.

McManus, C. and Lanier, J. M. (1987): Salmonella, Campylobacter jejuni, and Yersinia enterocolitica in raw milk. J. Food Prot. 50, 51-55.

Montenegro, M. A.; Ite, M. Bu.; Trumpf, T.; Aleksic, S.; Reuter, G.; Bulling, E. and Helmuth, R. (1990): Detection and characterization of fecal verotoxinproducing Escherichia colifrom healthy cattle. J. Clin. Microbiol. 28, 1417-1421.

Moustafa, M. K., Ahmed, A. A-H. and Marth, E. H. (1983): Occurrence of Yersinia enterocolitica in raw and pasteurized milk. J. Food Prot. 46, 276-278.

Paneto, B.R.; Schocken-Iturrino, R. P.; Macedo, C.; Santo, E. and Marin, J. M. (2007): Occurrence of toxigenic Escherichia coli in raw milk cheese in Brazil. Arq. Bras. Med. Vet. Zootec.59, 508-512.

O'Donnell, E. T. (1995): The incidence of Salmonella and Listeria in raw milk from bulk tanks in England and Wales. J. Soc. Dairy Technol. 48, 25-29.

Quinto, E. J. and Cepeda, A. (1997): Incidence of toxigenic Escherichia coli in soft cheese made with raw or pasteurized milk. Lett. Appl. Microbiol. 24, 291-295.

Rahn, K.; Renwick, S. A.; Johnson, R. P.; Wilson, J. B.; Clarke, R. C.; Alves, D.; McEwen, S.; Loir, H. and Spika, J. (1997): Persistence of Escherichia coli 0157:H7 in dairy cattle and the dairy farm environment. Epidem. Infect. 119, 251-259.

Rohrbach, R.W.; Draughon, F. A.; Davidson, P. M. and Oliver, S. P. (1992): Prevalence of Listeria monocytogenes, Campylobacter jejuni, Yersinia enterocolitica and Salmonella in bulk tank milk: risk factors and risk of human exposure. J. Food Prot. 55, 93-97.

Soomro, A. H.; Arain, M. A.; Khaskheli, M. and Bhutto, B.(2002): Isolation of Escherichia coli from milk and milk products in relation to public health sold under market conditions at Tandojam. Pakistan Journal of Nutrition 1, 151-152.

Steele, M. L.; McNab, W. B.; Poppe, C.; Griffiths, M. W.; Chen, S.; Degrandis, S. A.; Fruhner, L. C.; Larkin, C. A.; Lynch, J. A. and Odermeru, J. A. (1997): Survey of Ontario bulk tank milk for foodborne pathogens. J. Food Prot. 60, 1341-1346.

Vernozy-Rozand, C.; Montet, M.P.; Beradin, M.; Bavai, C. and Beutin, L. (2005): Isolation and characterization of Shiga toxin-producing Escherichia coli strains from raw milk cheeses in France. Lett. Appl. Microbiol. 41, 235-241. 
تعيين حدوث بكتيريا القولون المعدي المفرزة للسموم في الألبان الطازجة و الجبن القريش في

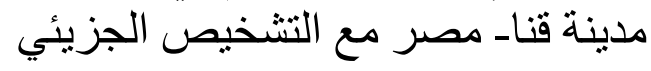

صبرى عبد الرجال حسن"، ليلى مصطفى كامل الملط"

*قسم الميكروبيولوجى، ** قسم المراقبة الصحية على الأغذية

كلية الطب البيطرى - جامعة جنوب الوادى - مصر لمربك

تم إجراء دراسة بكتيريولوجية على بعض الألبان والجبن القريش التى تباع في أسواق مدينة قنا - مصر وذلك

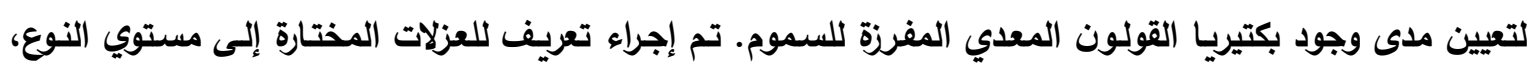

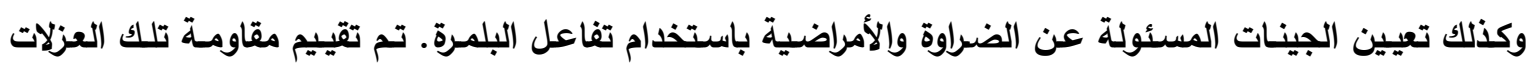

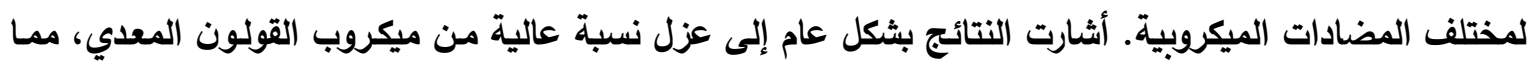

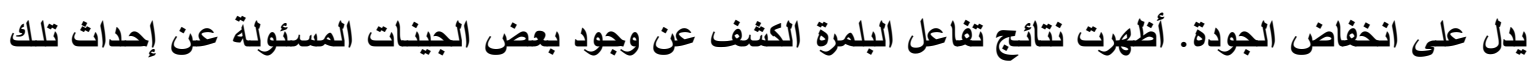

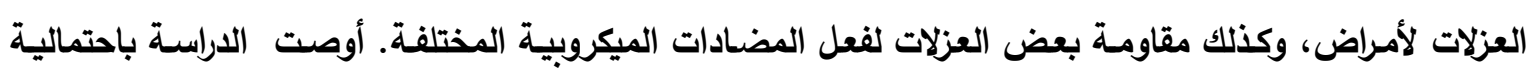

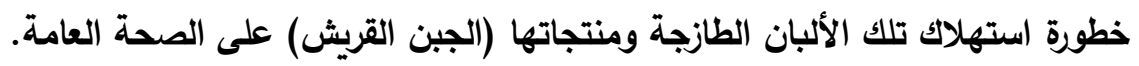

